\title{
The Ash Content of the Main Muscle Groups and Edible Offal Collected From Hares (Lepus europaeus Pallas)
}

\author{
Gabriela TĂRNĂUCEANU (FRUNZĂ)*, Cecilia POP, Paul Corneliu BOIŞTEANU \\ Faculty of Animal Science, University of Agricultural Sciences and Veterinary Medicine Iasi, 3, Mihail \\ Sadoveanu Alley, 700490, Romania \\ *Corresponding authors, e-mail: frunza.gabriela27@gmail.com
}

Bulletin UASVM Animal Science and Biotechnologies 73(1)/ 2016

Print ISSN 1843-5262; Electronic ISSN 1843-536X

DOI:10.15835/buasvmcn-asb: 11586

\begin{abstract}
The availability of hares (Lepus europaeus Pallas), unlike that of domestic rabbits, is restricted by hunting seasons. Rabbit meat, according to research from Spain, is a rich source of $\mathrm{K}, \mathrm{P}, \mathrm{Fe}$ and $\mathrm{Mg}$, but poor in $\mathrm{Na}$, being recommended for people with hypertension. The largest quantity of macro minerals studied in rabbit meat was determined for $\mathrm{K}$ and $\mathrm{P}$, and the most abundant micro minerals were $\mathrm{Zn}, \mathrm{Fe}, \mathrm{Cu}$ and $\mathrm{Mn}$. In hare meat, ash content is not sufficiently studied. The current low level of knowledge motivated the present study. The aim of this study was to establish the ash content for major muscle groups and edible offal of hares. The biological material used was collected from 49 hares with an average weight of $5.6 \mathrm{~kg}$, at the age of reproductive maturity (adults: 11-12 months). Different muscle groups (the muscles Cervicalis, Intercostalis, Longissimus Dorsi, Psoas major, Triceps Brachi, Biceps femoris, Semimembranosus) and the main edible offal (heart, liver, kidney) were sampled. The ash was determined by calcination (in Supertherm C311 oven calcination) at $550^{\circ} \mathrm{C}$. The results obtained were interpreted statistically (arithmetic mean $(\mathrm{X})$, standard deviation $(\mathrm{s})$, variance $\left(\mathrm{s}^{2}\right)$ and coefficient of variation $(\mathrm{V} \%)$ and the statistical significance of differences was tested using the ANOVA Single Factor algorithm ( $p>0.05 ; p<0.01 ; p<0.001)$. Ash content for the main muscle groups analysed varied from the lowest average values of $1.095 \%$ for the Intercostalis muscles, to the highest average values of $1.256 \%$, for Triceps brachii muscles.
\end{abstract}

Keywords: ash, hare, meat, muscles, edible offal

\section{INTRODUCTION}

Lean red meats (including hare meat) are an excellent source of high biological value protein, vitamin B12, niacin, vitamin B6, riboflavin, pantothenic acid, vitamin $\mathrm{D}, \mathrm{P}, \mathrm{K}, \mathrm{Fe}, \mathrm{Zn}, \mathrm{Se}$, mostly low in fat and sodium. They are also a source of long-chain omega-3 polyunsaturated fats and an important sources of a range of endogenous antioxidants and other bioactive compounds, including taurine, carnitine, carnosine, ubiquinone, glutathione and creatine (Hermida, 2006; Williams, 2007). The iron in meat is mostly heme-iron, which is well absorbed. Similar to the absorption of iron from an animal protein source, absorption of zinc is greater than from plant foods, as indicated by $\mathrm{Zn}$ requirements in vegetarians' diet, which is as much as $50 \%$ higher than for nonvegetarians. Red meats are also good sources of selenium, providing over $20 \%$ RDI per $100 \mathrm{~g}$ serve; lean meat is low in Na with a potassium/sodium ratio greater than five (Chan et al,,1995). All organ meats are extremely rich in vitamin B12, with more than $100 \% \mathrm{RDI}$ in $100 \mathrm{~g}$. for example, liver is a rich source of protein, $\mathrm{Fe}, \mathrm{Zn}$, riboflavin, niacin, vitamin A, and folate; kidney is rich in protein, thiamin, riboflavin, $\mathrm{Fe}$, and folate; heart is a good source of Fe and Zn (Williams, 2007).

\section{AIMS AND OBJECTIVES}

The aim of this study was to establish the ash content for major muscle groups and edible offal of hares. 
Tab. 1. The ash content for major muscle groups and offal of hares (\%)

\begin{tabular}{cccccc}
\hline Muscle groups & $\mathrm{X} \pm \mathrm{s}_{\bar{x}}$ & $\mathrm{~s}^{2}$ & $\mathrm{~V} \%$ & Min. & Max. \\
\hline Psoas & $1.168 \pm 0.19$ & 0.42 & 0.56 & 1.031 & 1.213 \\
\hline Intercostalis & $1.095 \pm 0.19$ & 0.42 & 0.56 & 1.006 & 1.208 \\
\hline Cervicalis & $1.158 \pm 12.65$ & 28.29 & 5.18 & 1.051 & 1.231 \\
\hline Semimembranosus & $1.201_{ \pm} 0.31$ & 0.69 & 0.92 & 1.088 & 1.241 \\
\hline Longisimus dorsi & $1.211_{ \pm} 0.3$ & 0.9 & 1.19 & 1.119 & 1.255 \\
\hline Triceps brachii & $1.256 \pm 0.41$ & 0.92 & 1.21 & 1.136 & 1.289 \\
\hline Biceps femoris & $1.201 \pm 0.06$ & 0.14 & 0.65 & 1.104 & 1.237 \\
\hline Heart & $1.138 \pm 2.81$ & 6.28 & 8.96 & 1.013 & 1.219 \\
\hline Liver & $1.123 \pm 1.5$ & 3.36 & 4.68 & 1.053 & 1.188 \\
\hline Kidney & $1.139 \pm 2.07$ & 4.14 & 5.64 & 1.026 & 1.193 \\
\hline
\end{tabular}

\section{MATERIALS AND METHODS}

The biological material used was collected from 49 hares ( 24 males and 25 females) with an average weight of $5.6 \mathrm{~kg}$, at the age of reproductive maturity (adults: 11-12 months). Different muscle groups (the muscles Cervicalis, Intercostalis, Longissimus Dorsi, Psoas major, Triceps Brachi, Biceps femoris, Semimembranosus) and the main edible offal (heart, liver, kidney) were sampled. The ash was determined by calcination (in Supertherm $\mathrm{C} 311$ oven calcination) at $550^{\circ} \mathrm{C}$. The results obtained were statistically interpreted. The measures of variability (mean (X), standard deviation (s), variance $\left(\mathrm{s}^{2}\right)$ and coefficient of variation $(\mathrm{V} \%)$ ) were calculated. The statistical differences between groups were determined by ANOVA Single Factor test $(p>0.05 ; p<0.01$; $\mathrm{p}<0.001$ ).

\section{RESULTS AND DISCUSSION}

The ash content for the main muscle groups and offal from hares varied from lowest average values of $1.095 \pm 0.19 \%$ for Intercostalis muscles to the higher average values of $1.256 \pm 0.41 \%$ for Triceps brachii muscles (tab. 1). In the edible offal, the mean values were similar for kidney $(1.139 \pm$ $2.07 \%)$ and heart $(1.138 \pm 2.81 \%)$, and a lower percentage was found for the liver $(1.123 \pm 1.5 \%)$. Following the statistical processing of the results, a high homogeneity of the population studied was observed, as indicated by the coefficient of variation (V\%) which did not exceed 10\% (tab. 1).

Following the variance analysis (ANOVA), insignificant differences were observed between genders in relation to the ash content of hare meat. The values obtained in this study were similar to those obtained by Skrivanco et al., 2008 (1.16\%) and by Konjević, 2007; other studies that analysed hare meat in terms of ash content are not currently available.

\section{CONCLUSION}

Analysing the differences between different muscle groups and offal by gender in hares, insignificant differences were observed between genders in relation to the ash content of hare meat. In terms of chemical composition, and in comparison with other types of meat, the meat of hares, as compared to that of other species, may be considered to be recommendable in nutrition and diet, being healthier, higher in protein, in polyunsaturated fatty acids ( $\omega 3$ and $\omega 6)$ and in minerals found in ash (approximately $1.22 \%$ in muscle and $1.13 \%$ in edible offal).

\section{REFERENCES:}

1. Chan W, Brown J, Lee S (1995). Meat, Poultry and Game. Fifth Supplement to McCance \& Widdowson's The Composition of Foods. London: The Royal 13 Society of Chemistry and the Ministry of Agriculture Fisheries and Food.

2. Hermida M, Gonzalez M, Miranda M, Rodriguez-Otero JL. (2006). Mineral analysis in rabbit meat from Galicia (NW Spain). Meat Science. 73 (4): 635-639.

3. Hernandez P. (2008). Enhancement of nutritional quality and safety in rabbit meat. In: Proceedings of 9th World Rabbit Congress "Meat Quality and Safety":1287-1299.

4. Konjević D. (2007). Hare brown (Lepus europaeus Pallas) and potential in diet of people today, Professional Work, 9: 288-291 
5. Skrivanco M, Hadžiosmanović M, Željka C, Nevijo Z, Filipović I, Kozačinski L, Florijančić T, Bošković I. (2008). The hygiene and quality of hare meat (Lepus
Europaeus Pallas) from estern Croatia. Archiv für Lebensmittelhygiene, 59: 180-184.

6. Williams PG. (2007). Nutritional composition of red meat, Nutrition \& Dietetics, 64(4): S113-S119. 